\title{
Idiosyncratic Shocks and Child Labor: Does Gender Matter? Evidence from Indonesia
}

\begin{tabular}{|c|}
\hline Bayu Kharisma $^{a}$, Elan Satriawan ${ }^{b}$, Lincolin Arsyad ${ }^{\text {b }}$ \\
\hline $\begin{array}{l}{ }^{\text {a }} \text { Department of Economics, Faculty of Economics and Business, University of Padjadjaran } \\
\text { Jl. Dipati Ukur No. } 35 \text { Bandung, 40132, Indonesia } \\
\text { b Department of Economics, Faculty of Economics and Business, University of Gadjah Mada } \\
\text { Jl. Sosio Humaniora No. 1, Bulaksumur, Yogyakarta, 55281, Indonesia } \\
\text { Corresponding author: bayu.kharisma@unpad.ac.id }\end{array}$ \\
\hline
\end{tabular}

Received: December 2016; Accepted: May 2017

\begin{abstract}
This paper aims to analyze the effect of various idiosyncratic shocks against child labor, working hours of children and school participation based on gender. Also, the role of the assets held by households as one of the coping strategies to mitigate the effects of such shocks. The results of random effect probit technique show that girls are more vulnerable and unprotected in the event of idiosyncratic shocks, especially those shocks caused by crop loss and the decline in household income due to price and quantity. Meanwhile, idiosyncratic shock that drives the existence of boys child labor is the death of the head or members of the household. Additionally, household assets play an important role in reducing the number of child labor and increase school participation but do not affect the child labor hours during a variety of idiosyncratic shocks.
\end{abstract}

Keyword: Idiosyncratic Shocks, Child Labor; Gender, Working Hours of Children, School Participation JEL Classification: J13, J16

\section{Introduction}

The high risk of revenue caused by idiosyncratic shocks is an unseparated condition from life in many developing countries. This situation is among other things characterized by the severe income fluctuations, volatile financial markets and thin or lacking formal insurance markets (Townsend, 1994). In addition to the low levels of income, some developing countries often suffer from the high-risk characteristics and the low probability of doing risk diversification (Fitzsimons, 2007). That is because the weakness of formal insurance markets in developing countries so that many households are forced to rely on informal insurance mechanisms, such as drawing personal savings, and credit transfer to ensure consumption due to the impact of such shocks.

Household's efforts to survive and to mitigate the shocks are vital for the sustainability of life of families in most developing countries. In this case, any unforeseen events or negative income shocks then will have indirect consequences including the emergence of family labor, informal institutions, safety nets and reduction of household spending and investment. One strategy that is commonly performed by households to anticipate the shocks, among others, is a change in the arrangement for several family members by lowering their previously allocated school time and converting it for work purpose. However, it indirectly has implications in the long term decline in the level of school participation and the increasing role of child labor in a household.

The use of child labor as a buffer stock as one strategy or mechanism is common, particularly in the agricultural households in developing countries to have consumption smoothing (Beegle, Dehejia \& Gatti, 2006). Skoufias \& Parker (2002) stated that the existence of child labor is strongly 


\section{Jurnal Ekonomi Pembangunan, 18 (1), 2017, 19-39}

associated with households' low ability to protect themselves from various shocks through formal and informal institutions. Thus, if households have limited access to the protection of formal and informal, then it will encourage parents to involve their children in some activities to earn income. Fitzsimon (2007) showed that the missing functionality of the labor market is believed to be one of the factors which caused the number of child labor in domestic work and agricultural activities.

The problem of child labor in Indonesia has been a concern since the economic crisis, which started in mid-1997. During the peak of the crisis in 1998 the Indonesian economy contracted by an unprecedented magnitude of over 13\%. This is a sharp turnaround from the high economic growth averaging around 7\% annually over the previous three decades (Priyambada, Sumarto \& Suryahadi, 2005). As Indonesian households were forced to adjust to the substantial fall in real income, it was feared that parents would be forced to withdraw their children from schools and send them to work to supplement family income.

Various studies related to shocks against child labor and participation have been a source of debate for policymakers, both from the perspective of microeconomics and macroeconomics. Jacoby \& Skoufias (1997) showed that the decrease in school participation rates and an increase in the labor market caused by both aggregate and idiosyncratic shocks. Households actively utilized child labor in performing consumption smoothing when faced with idiosyncratic shocks in Tanzania (Beegle, Dehejia \& Gatti, 2006). Kochar (1999a) identified that the men in India tried to increase their working hours to respond to unpredictable weather variation and growth in labor supply. Dehejia and Gatti (2002) showed that households tend to use child labor in reducing the variability of aggregate income.

Several empirical results indicated that the presence of the shocks tends to increase the use of child labor along with the decline of participation rates. However, thereis some evidence to contradict these findings. Barros, Mendonça \& Velazco (1994) showed that in eight of the largest metropolitan areas in Brazil, the level of child labor was higher for low poverty levels and high economic growth. Child labor was greater, and school participation decreased when exposed to high levels of wages (Duryea \& Kuenning, 2001). Similar results were obtained in Brazil and Nicaragua where data showed that children tend to work as long as economic conditions continued to improve as their coffee production boom (Kruger, 2007).

Many empirical studies emphasize the importance of the credit markets and other safeguards to buffer or anticipate the impact of shocks. Nevertheless, it is undeniable that the use of self-insurance mechanism has been widely used as a tool to perform household consumption smoothing through ownership of household assets (Dercon, 2005). The role of household assets against child labor has an ambiguous effect (Bhalotra \& Heady, 2003). In this case, the ownership of assets can reduce child labor, but on the other hand, it only may be able to provide relatively small protection because the price of the asset can be decreased when many households sell assets during shocks.

Since the findings are contradictory and there is an emergence of the issue of using child labor as a buffer to dampen the shocks, this study aims to investigate the effect of various idiosyncratic shocks against child labor, working hours of children and school participation. Also, the role of the assets held by households as one of the coping strategies to mitigate the effects of such shocks.

The empirical model used in this study to adopt a previous study conducted by Dillon (2008) addressing the deficiencies or weaknesses in the model. First, this study adds a variety of statistical tests before estimating random effect probit among others are a test of serial correlation to ensure there is no correlation in the error and the likelihood ratio test (LR), wald test and lagrange multiplier (LM) to ensure the influence of random effects. The test is important in order 


\section{Jurnal Ekonomi Pembangunan, 18 (1), 2017, 19-39}

to estimate produced consistently and efficiently (Arulampalam, 1998; Greene \& McKenzie, 2012). Second, the test is to make sure that a variety of idiosyncratic shocks is unpredictable and of transitory nature so that the resulting estimates are not biased (Beegle, Dehejia \& Gatti, 2006). Third, adding the province dummy variables to control or capture the effect of differences in wages, labor demand conditions and prices between provinces caused by aggregate shocks, such as the economic crisis in Indonesia (Bhalotra \& Heady, 2003; Levinsohn, Berry \& Friedman, 2003). Third, the data used in this study differs from previous study in estimating child labor in Indonesia (Priyambada, Sumarto \& Suryahadi, 2005) Priyambada, Sumarto \& Suryahadi, (2005) used survey data of 100 villages just focus on rural areas, which were quite poor so it was not appropriate to generalize the produced estimates for the whole country case studies (Cameron, 2001). Meanwhile, one of the advantages of IFLS data is the availability of rich information on child labor and various idiosyncratic shocks so that the analysis in this study can be conducted more in-depth and comprehensive. Lastly, the advantages of this study with other studies in Indonesia (Cameron and Worswick, 2003) related to the estimated hours of work is the use of panel data in their analysis, whereas previous studies using cross section data so that the possibility is still there is a problem concerning matters that are not observed that can affect outcomes.

\subsection{Previous research}

There are various empirical studies related to child labor, the allocation of time to work, and school participation involved and the results of different approaches. (Priyambada, Sumarto \& Suryahadi, 2005) conducted a study on child labor during the economic crisis in Indonesia. The data used in the study was a survey of 100 villages were estimated by probit and IV-Probit. The study results indicate a strong correlation between child labor and poverty. In addition, poverty is an important factor in deciding whether a child will be told to work or not, but if it works then it does not eliminate the chance of the child to acquire formal education. In fact, children from poor households may still be in school by doing part-time jobs to pay for his education. The main difference with previous studies in Indonesia is on emphasizing the importance of poverty as a factor in determining child labor and school. However, the study does not explain the impact of idiosyncratic shocks comprehensive review of child workers and school participation. The criticism of the study are related to the data used. Data obtained from the 100 village survey which was used in the study was not designed as a national representative sample and just focus on poor rural areas and therefore it is not appropriate to generalize the context of the country as a whole (Cameron, 2001).

Dehejia and Gatti (2002) conducted a study to see the effect of the variability of income and access to credit against child labor. The data used came from the ILO at intervals of 10 years in 172 countries with OLS and Tobit estimation techniques. The results of his studies found a negative relationship between child labor and access to credit. Households were significantly using child labor in response to the variability of aggregate income in countries with less developed financial markets. In addition, the emergence of working children is commonly due to financial constraints so that households actively use child labor to dampen the volatility of earnings. The difference with previous studies is the aggregate nature of the data used, while other studies generally use data at the household level. In addition, the study was not discussed on the issue of working hours of children and gender disparities.

(Beegle, Dehejia \& Gatti, 2006) examined the relationship between income shocks using a proxy crop loss, household asset ownership and child labor with estimation techniques OLS and fixed effects. The results of the study showed that crop loss shocks leading to a significant increase in child labor. In addition, ownership of assets 


\section{Jurnal Ekonomi Pembangunan, 18 (1), 2017, 19-39}

capable of balancing about $80 \%$ of the shocks. Results in line with other research studies in Tanzania (Dehejia \& Gatti, 2002; Bandara et al, 2014), in which the farmer households generally use of child labor in shock address any crop loss. However, the study did not explain further the development and the negative consequences of child labor in the long term and how the role of access to credit in reducing child labor, as discussed in previous studies in Tanzania.

Jacoby \& Skoufias (1997) studied poor households in their use of child labor when faced with income shocks. The data used is ICRISAT Village Level Studies survey and time allocation children aged 5-18 years from 40 households 6 villages in India with fixed effect estimation techniques. The results of his studies identify market imperfections and constraints that credit markets may affect the decision of schoolchildren. The weakness in the study is only focused on the participation of schools, but not to child labor are likely to be directly affected by the shocks due to the inability of households to access credit. In addition, the study only focused on aggregated risk to the level of educational attainment but it does not explain the impact on child labor and working hours of children.

Cameron and Worswick (2003) examined the labor supply in response to the disastrous harvests in Indonesia. The data used is the Indonesian Family Life Survey (IFLS) in 1993 with Constant estimation techniques Labor Supply Case (CLS) and Variable labor Supply Case (VLS). The study results indicate that the crop loss had no effect on the increase in the number of hours worked in Indonesia, especially for individuals aged below 18 years, to be more likely dominated by child laborers. The disaster crop loss had significant negative effect on household members aged 18 to 65 years with a level of secondary education. The study results are in line with previous findings (Bandara et al, 2014; Dillon, 2008; Dehejia and Gatti, 2002; Beegle et al, 2006) which emphasizes working hours of children as a buffer for shocks income. Meanwhile, the difference is emphasizing the importance of efforts to reallocate workers who previously worked on unproductive activities become more productive by improving the labor market in rural felt still relatively weak. One drawback to the study is the use of cross-section data so that it is likely to be a problem concerning the things which are not observable that can affect outcomes.

Bandara et al (2014) examined the impact of income shocks and not against child labor income and household asset ownership and access to credit as a mechanism to mitigate transitory shocks in Tanzania. The data used comes from the Tanzania National Panel Survey in 2009 and 2011 with the OLS estimation techniques as well as fixed effect. The results of the study identify the positive influence crop loss on working hours of boys in the agricultural sector. In addition, the disaster had an adverse effect on school attendance of girls, of which more than 70 percent increase in dropouts. The existence of access to banking and bank accounts can act as a buffer to mitigate the effects of shocks that could reduce workers' boys and girls working hours. Meanwhile, household assets play a role in reducing the working hours of girls than boys. The study results are consistent with previous studies that crop loss significantly affect the increase in the number of hours worked (Dehejia and Gatti, 2002; Beegle et al, 2006). The criticism about the study is pointed towards the fact that the study only discusses shocks crop loss and the death of a parent but it did not address other idiosyncratic shocks, such as illness, a decrease in household income, unemployment and others, as well as the shocks that are aggregated.

Dillon (2008) conducted a study on the effect of health shocks and the production of child labor and school attendance in northern Mali, Africa. Data derived from EPSAM 2006 related to human capital and production activity of households with random effects probit estimation techniques and multivariate probit. The study results showed that the production shocks emanating from pests during the harvest period to encourage households 


\section{Jurnal Ekonomi Pembangunan, 18 (1), 2017, 19-39}

to dismiss the child goes to school and work in the agricultural sector. In addition, shocks health to women can increase children's participation in activities family business and children. The findings of Dillon (2008) are in line with previous studies that failed to harvest positive effect on the number of working hours and child labor. In addition, stressed the importance of the assets as a coping strategy to dampen the shocks. The critique of the study is about the fact that it only discussed the shocks caused by crop loss and health, but did not address other idiosyncratic shocks. Moreover, in the estimation of random effects probit they did not perform a variety of tests, such likelihood ratio test (LR), wald test and Lagrange multiplier (LM) to test for the presence and influence of random effects autocorrelation test.

Various empirical studies show the positive influence of shocks to child labor and working hours of children. However, there is some empirical evidence to contradict these findings. Barros et al (1994) analyzed the effect of poverty in urban areas of Brazil by using household survey data and estimation techniques generalized ordered logit. The study results showed that in 8 (eight) largest metropolitan areas, the level of child labor is higher during periods of low poverty and high economic growth than during the period of declining economic growth and high levels of poverty. The study results in line with Duryea \& Kuenning (2001) and Kruger (2004) that in the aggregate income shocks, households generally choose investment strategies to improve children's education compared to hiring and reduce the level of school participation of children. Meanwhile, criticism of the study is the object of research is valid only for 8 metropolitan area that is not necessarily true for all regions of Brazil.

Duryea \& Kuenning (2001) conducted a study on school attendance, child labor and the local labor market in urban Brazil used data The Pesquisa Nacional de Amostra Domicilios with bivariate probit models. The study results showed that the higher incidence of child labor and education attendance decreased when confronted with higher wage levels. The study results contrast with previous research that stated that child labor and child work hours tend to increase when the condition of income shocks. The critique of this study is pointed to the fact that it just observed the aggregate shocks and did not discuss the terms of idiosyncratic shocks.

Kruger (2004) analyzed the effect of coffee production against child labor and school attendance in urban areas of Brazil using panel data from household surveys 7 rounds with fixed and random effects technique. The study results indicate that child labor tends to increase, while attendance declined during the period of improved economic conditions for their coffee production boom. These results contradicted by the findings in various countries such as Guatemala, South Africa, Indonesia, and Tanzania. One criticism of the study is to the fact that it only viewed shocks as aggregate and did not compare its impact with idiosyncratic shocks.

\section{Research Method \\ 2.1 First Model}

The estimation technique used in the first model is a random effects probit. The purpose of using the estimation technique is to control for household unobservable, such as parental preferences that have large effects on children's schooling and work decisions. Households fixed effect estimation technique would not be able to control effect of other household characteristics such as household asset or parental education which potentially varies among children, and may influence children's time allocation pattern to work or to study (Dillon, 2008). Household and individual specific covariates are given as $X_{i h}, c_{h}$ is a household effect on each child. In addition, a child/household unobservable $\varepsilon_{i h}$ can be combined in a composite error term: $v_{i h}=c_{h}+\varepsilon_{i h}$. The following equation is specified such that: 


\section{Jurnal Ekonomi Pembangunan, 18 (1), 2017, 19-39}

$L^{C^{*}}{ }_{i, h}=B \mathrm{X}_{i, h}+V_{i, h}$

where $L^{C}{ }_{i, h}=1$ if $L^{C^{*}}{ }_{i, h}>0$

$$
=0 \text { otherwise }
$$

and obtain the distribution of $\mathrm{L}_{\mathrm{i}, \mathrm{h}}^{\mathrm{C}}$

$$
\begin{aligned}
P\left(L_{i h}^{C}=1 \mid X_{i h}, c_{h}\right) & =P\left(L_{i h}^{C^{*}}>0 \mid X_{i h}, c_{h}\right) \\
L_{i h}^{C^{*}} & =P\left(e_{i h}>-\beta X_{i h} \mid X_{i h}, c_{h}\right) \\
& =1-\Phi\left(1-\beta X_{i h}\right)=\Phi\left(\beta X_{i h}\right)
\end{aligned}
$$

where $\Phi$ is the standard normal cumulative distribution function. Furthermore, taking into account a variety of variables shocks and household assets in equation (1), the equation can be rewritten as follows :

$$
L_{i h t}^{C^{*}}=\beta X_{i h t}+\lambda \theta_{i h t}+\phi_{t}+\mu a_{i h t}+c_{h}+\varepsilon_{i h t}
$$

where $\mathrm{L}^{\mathrm{C}^{*}}{ }_{i h t}$ is child labor ${ }_{i}$ in a household ${ }_{h}$ in year ${ }_{t}, X_{i h t}$ is household and individual specific covariates, $c_{h}$ is a household effect on each child, $\theta_{i h t}$ is the idiosyncratic shocks, and $\phi_{t}$ is year dummy variables. Meanwhile, $a_{i h t}$ is household asset ownership and $\varepsilon_{i h t}$ is the error term. In addition, this study uses dummies province variables to capture any effects of interprovincial differences in wages and prices (Bhalotra \& Heady, 2003; Levinsohn, Berry \& Friedman, 2003).

\subsection{Second Model}

The second model is used to estimate a variety of idiosyncratic shocks to the working hours of children through techniques fixed effect at the household level (Bandara, Dehejia \& Rouse, 2014; Beegle, Dehejia \& Gatti, 2006). The model used can be given by :

$$
l_{i h t}=\rho_{h}+\beta X_{i h t}+\lambda \theta_{i h t}+\phi_{t}+\mu a_{i h t}+u_{i h t}
$$

where $\rho_{h}$ is a fixed effects term on the household level, $l_{i h t}$ is time allowed for work for the child $i$ in a household $h$ in year $t, \phi_{t}$ is the year dummy variables and $u_{i h t}$ is an error term. In this model, parents' level of education is used as a proxy for parental income to avoid the possible simultaneity between child labor and parental income (Bandara, Dehejia \& Rouse, 2014). The reason of this is because parents' education is highly unlikely to be simultaneously determined with child labor.

The OLS estimates in equation (4) will be biased if some household unobservable could be correlated with children's labor hours. For example, households that are less forwardlooking may be more vulnerable to various shocks. Also, households that are less careful in the management of its assets tend to send their children to work because it placed less value on the formal education. Therefore, to control time invariant unobserved heterogeneity, it is carried out through a fixed effect estimation at the household level in the specification above.

Before performing an estimate of each model, the step that must be done is ensuring that idiosyncratic shocks are unpredictable and transitory (Beegle, Dehejia \& Gatti, 2006; Debebe, 2010; Bandara, Dehejia \& Rouse, 2014). If a household can predict or forecast the shocks and the use of child labor and the ownership of assets as a buffer, the estimate will be biased. Therefore, to test this issue, it was estimated using probit at any shocks. In this case, the shock in 2000 was estimated to child labor and ownership of assets in 1997 as well as the characteristics of the household and children through the following equation:

$\operatorname{Pr}\left(\right.$ shock $\left._{i h t}=1\right)=f\left(\right.$ child labor $\left._{i h t \llbracket 1}, X_{i h t}\right)$

furthermore, to show that the shocks are transitory it is necessary to analyze it. If the shock does not correlate overtime then the shock is transitory in nature. On the other hand, if there is a correlation then the shock is not a transitory one. Therefore, this can be investigated by examining the following equation: 


\section{Jurnal Ekonomi Pembangunan, 18 (1), 2017, 19-39}

$$
\operatorname{Pr}\left(\operatorname{shock}_{i h t}=1\right)=f\left(\operatorname{shock}_{i h t \square 1}, X_{i h t}\right)
$$

lastly, Greene \& McKenzie (2012) identified that to estimate the random effects probit there should be a variety of statistical tests including a likelihood ratio test (LR), Wald test and Lagrange multiplier (LM) to find out where the influence of random effects. Besides, the serial correlation test can also be important to ensure there is no correlation in error.

\subsection{Data Description}

The data used in this paper is IFLS (Indonesia Family Life Survey), particularly those from 1997 and 2000, and it is used to capture the occurrence of several events in Indonesia which has a risk associated with the shocks of child labor, working hours of children and school participation since the economic crisis, which started in mid-1997. In addition, this paper uses panel data from 1997 and 2000 are derived from IFLS 2 and 3 because it contains important information in this study, especially about the amount of observation of children aged 5-14 in 1997 is not expected to experience problems fairly high attrition.

Child labor variables in this study were children who worked while going to school. Meanwhile, the definition of working hours of children in this study using the definition given by the ILO (International Labor Organization) that children who are active in economic activity aged 5-14 years to find wages over the last week or the last week of work. How long the child is involved as workers can be seen from the number of hours of work done in the job. If working hours are too long, that might cause the child to lose time to be able to do other activities such as playing, going to school, taking a break and can eventually interfere with the child's development process.

The measurement of idiosyncratic shocks in this study is a variety of shocks over the past year or 12 months, among others, the death of the head or member of the household, the disease suffered by the head and members of the household, crop loss, loss of business sector due to natural disasters such as fires, earthquakes and other disasters, household unemployed or failure of business, and a decline in household income due to lower prices and the quantity produced.

The households asset ownership used in this study includes the house occupied, houses or other buildings, livestock or poultry, vehicles (cars, bikes, bicycles, boats and motorcycles), household appliances (radios, tape recorders, refrigerators, sewing tools, washing machine and others), savings accounts or certificates of deposits or shares, receivables, jewelry, furniture and appliances as well as other assets. Ownership of household assets in the form of land is not taken into account because it could be positively related to child labor demand so that they can make estimates biased (Beegle, Dehejia \& Gatti, 2006).

Descriptive statistics in Table 1 shows that the economic shocks that have the most impact for one year before the survey due to their illness or the head of the household members who require hospitalization or continuous need of medical care by 8.7 percent. Meanwhile, the economic shocks that have the smallest effect caused by the decrease in household income or business sector due to fires, earthquakes and other disasters at 1.1 percent.

The total numbers of households in an average household reach 5 to 6 people whose children are girls with an average age of 11 years. The average number of children aged 5-14 years participating schools is quite high, reaching 82.8 percent, while the activity in work and school only 2.8 percent of the working hours, reached 2,380 hours per week. This indicates that the number of children aged 5-14 years who attend school was quite high, although they spent some of their time for working purpose, they still did their school activities. 
Avalaible online at http://journals.ums.ac.id

Jurnal Ekonomi Pembangunan, 18 (1), 2017, 19-39

Table 1 Summary Statistics of Key Variables

\begin{tabular}{|c|c|c|}
\hline Variables & Mean & Std. Dev. \\
\hline Disasters (yes=1) & 0.011 & 0.106 \\
\hline Unemployment (yes =1) & 0.025 & 0.156 \\
\hline Death $($ yes $=1)$ & 0.052 & 0.223 \\
\hline Sickness (yes =1) & 0.087 & 0.281 \\
\hline Crop loss $($ yes $=1$ ) & 0.076 & 0.266 \\
\hline Price fall (yes $=1$ ) & 0.047 & 0.211 \\
\hline Household size & 5.628 & 1.957 \\
\hline Household assets (log) & 15.686 & 2.202 \\
\hline The farm business $($ self-owned $=1$ ) & 0.341 & 0.474 \\
\hline Household age (years) & 44.544 & 10.988 \\
\hline Household sex $($ Women $=1)$ & 0.115 & 0.319 \\
\hline Mother's education (years) & 4.715 & 4.028 \\
\hline Father's education (years) & 5.012 & 4.419 \\
\hline Child work (yes =1) & 0.028 & 0.165 \\
\hline Child labor hours & 2.38 & 10.879 \\
\hline Child age (years) & 11.006 & 3.236 \\
\hline Child sex (boys $=1$ ) & 0.44 & 0.496 \\
\hline School Participation (yes $=1$ ) & 0.828 & 0.378 \\
\hline Rural (yes=1) & 0.573 & 0.495 \\
\hline
\end{tabular}

Sources: IFLS2 and IFLS3

\section{Result and Discussion}

\subsection{Estimation Results of Idiosyncratic} Shocks

The first stage in this research is to ensure that idiosyncratic shocks cannot be predicted by child labor and ownership of household assets. In Table 2 shows that working children aged 5-14 years and ownership of household assets in 1997 can predict shocks when the head or members of the household are unemployed or experienced a business failure in 2000. This is demonstrated by the statistically significant effect on child labor, and household assets 1997 with head or member of the household who are unemployed or failure of business in 2000 amounted to 1 and 10 percent. Thus, it can be concluded if the head or members of the household are unemployed or experiencing business failure then households will likely involve a child to work and use of household assets as a coping strategy to dampen such shocks.

The next stage is to test against any shocks to ensure that such shocks are transitory. Based on estimates that any shocks in 1997 can predict shocks that occurred in 2000. This is reflected in the statistically significant effect of the shocks in 1997 to shocks in the year 2000 at the rate of 1 percent. However, with the use of fixed effect estimation techniques at the household level to control the time invariant unobserved heterogeneity and did robustness check is expected to address potential biases (Beegle, Dehejia \& Gatti, 2006; Debebe, 2010; Bandara, Dehejia \& Rouse, 2014). 
Avalaible online at http://journals.ums.ac.id

Jurnal Ekonomi Pembangunan, 18 (1), 2017, 19-39

Table 2 Predicting Idiosyncratic Shocks in 2000

\begin{tabular}{|c|c|c|c|c|c|c|}
\hline \multirow[t]{2}{*}{ VARIABLES } & \multicolumn{6}{|c|}{ Idiosyncratic Shock 2000} \\
\hline & Disaster & Death & Sickness & $\begin{array}{c}\text { Crop } \\
\text { loss }\end{array}$ & Unemployment & $\begin{array}{c}\text { Price } \\
\text { fall }\end{array}$ \\
\hline \multirow{3}{*}{ Child work (1997) } & (1) & $(2)$ & (3) & (4) & (5) & (6) \\
\hline & 0.0000 & 0.012 & 0.024 & 0.006 & $0.021 * * *$ & 0.004 \\
\hline & {$[0.006]$} & {$[0.012]$} & {$[0.015]$} & [0.015] & {$[0.007]$} & {$[0.011]$} \\
\hline \multirow[t]{2}{*}{ Household assets (1997) } & 0.0000 & 0.0020 & 0.0000 & 0.0000 & $-0.001^{*}$ & -0.001 \\
\hline & {$[0.000]$} & {$[0.001]$} & [0.001] & [0.001] & [0.001] & {$[0.001]$} \\
\hline \multirow[t]{2}{*}{ Disaster (1997) } & $0.047 * * *$ & 0.016 & -0.0140 & 0.0200 & 0.014 & -0.008 \\
\hline & {$[0.005]$} & {$[0.018]$} & {$[0.025]$} & [0.023] & [0.009] & {$[0.022]$} \\
\hline \multirow[t]{2}{*}{ Death (1997) } & -0.001 & $0.128 * * *$ & $-0.032^{* * *}$ & 0.005 & $0.010^{*}$ & 0.005 \\
\hline & {$[0.004]$} & {$[0.007]$} & [0.012] & [0.011] & {$[0.006]$} & [0.009] \\
\hline \multirow[t]{2}{*}{ Sickness (1997) } & 0.001 & $-0.017 * *$ & $0.180 * * *$ & 0.003 & $0.009 *$ & 0.0000 \\
\hline & [0.003] & {$[0.008]$} & [0.007] & [0.009] & [0.005] & [0.007] \\
\hline \multirow[t]{2}{*}{ Crop loss (1997) } & 0.004 & -0.001 & 0.011 & $0.144 * * *$ & -0.004 & -0.011 \\
\hline & {$[0.004]$} & {$[0.009]$} & [0.011] & {$[0.006]$} & {$[0.007]$} & {$[0.007]$} \\
\hline \multirow[t]{2}{*}{ Unemployment (1997) } & 0.007 & $0.024 * *$ & $0.043^{* * *}$ & -0.013 & $0.080 * * *$ & 0.012 \\
\hline & {$[0.005]$} & {$[0.012]$} & [0.014] & [0.018] & [0.005] & [0.013] \\
\hline \multirow[t]{2}{*}{ Price fall (1997) } & -0.008 & -0.004 & 0.001 & -0.007 & $0.011^{*}$ & $0.109 * * *$ \\
\hline & {$[0.006]$} & {$[0.010]$} & [0.013] & [0.010] & {$[0.006]$} & [0.007] \\
\hline Pseudo R2 & 0.1309 & 0.1358 & 0.1378 & 0.2498 & 0.1942 & 0.1396 \\
\hline $\mathrm{N}$ & 9063 & 9063 & 9063 & 9063 & 9063 & 9063 \\
\hline
\end{tabular}

Marginal effects; robust standard errors in brackets
Additional controls: Household head sex (women =1), Household age (years), Rural (yes=1), Child sex (boys = 1), Child age (years) and the farm business (self-owned=1), Household size, Mother's education (years), Father's education (years) are included but not reported.

${ }^{*} \mathrm{p}<0.1,{ }^{* *} \mathrm{p}<0.05, * * * \mathrm{p}<0.01$

Lastly, in Appendix 1 and Appendix 3 show that the testing results of child labor and school participation models through the likelihood-ratio test, wald test and LM test indicated the presence of random effects. Thus, it can be concluded that the model is appropriate and efficient for child labor and school participation is a probit random effects models rather than probit. Meanwhile, the value of Prob> F did not show statistically significant sign. This indicates no correlation in error.

\subsection{Effects of Idiosyncratic Shocks to Child Labor}

Appendix 1 shows that idiosyncratic shocks emanating from the disaster crop loss and a decrease in household income due to falling prices and the quantity produced over the last year had a positive influence on the probability of girls to be workers. This indicates that girls are more vulnerable and unprotected in the event of such an idiosyncratic shocks that households tend to involve girls to work as a coping strategy in reducing such shocks.

Last year crop loss had a positive influence on girls child labor and it was statistically significant at 5 percent level. This finding indicates that girls are in a relatively high risk of crop loss than boys. In times of drought and prolonged drought, girls were commonly instructed to carry water, and it took hours to collect water, looking for fodder, fuel wood, including food (UNDP, 2007).

Moreover, the pressure on girls to work will increase over the scarcity of water because they are given the responsibility for household and agricultural production as well as providing care 


\section{Jurnal Ekonomi Pembangunan, 18 (1), 2017, 19-39}

for other family members affected by the disease due to the scarcity of water. Therefore, girls have the possibility to leave school and become a worker having to face the natural resources that become increasingly limited, caring for the family illness, and helping parents to obtain additional household income. Thus, girls tend to be more vulnerable than boys as for uncertainty and climate change. This result is consistent with previous studies indicating that girls are more susceptible to shocks caused by crop loss (Cameron and Worswick, 2001; Bandara, Dehejia \& Rouse, 2014).

Furthermore, the decline in household income due to lower prices and the quantity produced over the last year had a positive influence on the likelihood of girls to be employed and it is statistically significant at 5 percent level. The decline in agricultural production and rising prices of basic necessities is strongly associated with limited natural resources and adverse climatic conditions. It indirectly affects the prices of goods, especially basic needs, and it also reduces household income. For some households living in rural areas, such an impact makes life increasingly difficult due to increased production costs. Therefore, parents will involve girls for work purpose as the natural resources become increasingly limited and the nature conditions are unfavorable. These findings support previous studies that girls tend to be involved to work when faced with limited natural resources (UNDP, 2007).

Meanwhile, idiosyncratic shock that drives the existence of boys child labor is the death of the head or members of the household. Death of the head or member of the household over the last year had a positive influence on young workers and was statistically significant at 10 and 5 percent. These results indicate that, if the head or member of the household dies it will affect the viability of survival. Therefore, parents will encourage their children to work, especially boys to seek additional revenue with the hope that the wages workers boys much bigger than girls.
Finally, assets owned by households in each model have a negative influence on the presence of working boys and girls and statistically significant at 1 and 5 percent level. This finding is consistent with studies conducted in Mali (Dillon, 2008) in that the household assets negatively affect child labor, especially boys who work in family businesses and farms.

\subsection{Effects of Idiosyncratic Shocks to Child Labor Hours}

Appendix 2 shows that the decline in household revenue resulting from price and production declines negatively affect the number of hours of boys between 2.769 to 2.986 hours per week as well as statistically significant respectively at 10 and 5 percent. This suggests a household's decision to reduce the working hours of a boy at the time of the shock of falling household incomes resulting a decline in prices and production. Meanwhile, a variety of idiosyncratic shocks had no statistically significant effect on girls' working hours.

The findings are consistent with research in Indonesia (Cameron and Worswick, 2001) that during shocks, doing household coping strategies to protect the boy by cutting spending on girls' education. Thus, the reduction in education spending that has implications for the declining number of working hours for the boys. This further strengthens the consideration of parents to prioritize boys than girls to stay in school when faced with difficult conditions (Dreze and Sen, 2011).

Finally, household assets ownership in any models is not statistically significant in reducing the working hours of children both boys and girls. This indicates that the role of assets as a coping mechanism carried by households to cope with shocks has not been effective to decrease the number of working hours for children aged 5-14 years. The findings are consistent with studies in Indonesia are on the fact that the assets owned by households are generally illiquid, although there are some relatively liquid assets 


\section{Jurnal Ekonomi Pembangunan, 18 (1), 2017, 19-39}

such as cash and stock, but is not able to mitigate the effect of the shock of its value has decreased quite dramatically in line with the crisis economy in Indonesia (Thomas \& Frankenberg, 2004). Additionally, their limitations assets owned by household, particularly in rural and the distance barrier to trade assets, such as household relatively difficult to sell assets because of the distance between households by source trade far enough.

Another study in Indonesia showed that the coping mechanisms through migration and remittances can reduce the supply of child labor, including the number of working hours significantly compared with assets household. The existence of migration reduces the number of hours of work done by all the number of family members, including children, at 26 hours per week (Nguyen \& Purnamasari, 2011). Thus, the role of a much larger migration influence than household assets in reducing the number of working hours child. The same result occurred in Nicaragua that remittances can help household income in reducing working hours by 2.2 hours per child week, especially in urban areas (Andersen \& Tejerina, 2007).

\subsection{Effects of Idiosyncratic Shocks to School Participation}

The estimation result in Table 5 shows that the decline in household income or business sector due to price and production had a positive effect on school participation rate of boys amounted to 0.183 and was statistically significant at 10 percent level. Meanwhile, the decline in household income or business sector due to fires, earthquakes and other disasters positive effect on children's school participation of boys ranged from 0.410 to 0.429 and is statistically significant at 10 percent level. Specifically, these findings indicate that when the idiosyncratic shocks, households have limited resources and do not have broad access to the credit market or the labor market. Therefore, one of the coping strategies that often made a household budget is to reduce the education of girls of school age. It is an indirect consequence of the increase in school participation and a decrease in working hours for boys.

Specifically, these findings indicate that when it happens, households have limited resources and does not have broad access to the credit market or the labor market. Therefore, one of the coping strategies that do is to reduce the budget of girl's education. In this case indirectly it has consequences on the increase school participation and a decrease in working hours for boys.

Crop loss over the last year negatively affects school participation rate of girls was 0.119 and statistically significant at 10 percent level. These findings are consistent with studies in Indonesia that when households affected by shocks to crop loss then one attempts to dampen such shocks is to reduce the budget of the education of girls. With the reduction in the education budget of the girls indirectly impact on the low level of participation of girls than boys (Cameron and Worswick, 2001).

Household assets ownership has a positive influence on school participation boys and girls as well as statistically significant at 1 percent level. The findings show that the ownership of assets has more influence on the participation of boys than girls' participation. These results show the priority of parents for boys than girls. This indicates that the larger the household asset ownership, the tendency to send their children to school will be higher. This finding is consistent with studies conducted in Tanzania (Beegle, Dehejia, \& Gatti, 2006) and Mali (Dillon, 2008) that the ownership of assets of the household can increase the probability of children school participation significantly.

\section{Conclusion}

Research on the influence of idiosyncratic shocks on child labor was mostly done by involving the empirical results and different approaches. An important contribution of this research is to use a variety of idiosyncratic shocks that are comprehensive including crop loss, disease suffered by head or household members 


\section{Jurnal Ekonomi Pembangunan, 18 (1), 2017, 19-39}

who require hospitalization or continuous need of medical care, acceptable losses the business sector (due to fires, earthquakes and disasters others), the head of the household is not working or failure of a business, the decline in household income due to lower price or quantity of goods produced. Lastly, This study gives empirical contribution because similar studies conducted in Indonesia is relatively limited, especially one that looks at the influence of various idiosyncratic shocks against child labor, working hours and participation of students which are associated with gender disparities.

The existence of child labor as a buffer for household life cannot be separated because of differences in the underlying economic conditions and choices household income among economic actors, financial market conditions are incomplete, investment decisions are constrained by credit and resource constraints. Thus, households will perform smoothing consumption by reducing investment in education or involve a child to work.

Girls are more vulnerable and unprotected in the event of idiosyncratic shocks, especially those caused by crop loss and declining household income due to price and quantity. This indicates that girls tend to be more at risk for uncertainty income and climate change than boys. Therefore, girls have a probability to become workers, especially in agriculture and domestic in order to dampen the shocks. Meanwhile, idiosyncratic shock that drives the existence of boy's child labor is the death of the head or members of the household. This results indicate that, if the head or member of the household dies it will affect the viability of survival. Therefore, parents will encourage their children to work, especially boys to seek additional revenue with the hope that the wages workers boys much bigger than girls.

Ownership of household assets as a coping strategy plays an important role in reducing the number of child labor and increase school participation, but not effective in reducing the working hours of children. This is due to the assets owned by households are generally illiquid, although there are some assets that are relatively liquid, but is not able to mitigate the effects of shocks because its value has decreased in line with the economic crisis in Indonesia. In addition, the considerable distance constraints to sell assets to the center of trade and the impact of the economic crisis is causing the loss of property households that have limitations to dampen the shocks are idiosyncratic.

Critics of this study are not considering the impact of aggregate shocks. It is important to remember these shocks may have a different effect on participation in education and child labor. Thus, further studies are expected to take into account the impact of idiosyncratic and aggregate shocks as well as the role of remittances on child labor and school participation. Another limitation is the data used in this study, the IFLS 1997 and 2000. This is because the data IFLS in 2007 has experienced a change in describing various economic shocks faced by households.

\section{Acknowledgments}

This research was partially supported by Doctoral Research Grant from Direktorat Jenderal Pendidikan Tinggi (Dikti). We thank our colleagues from Doctoral Program of Economics, Gadjah Mada University who provided insight and expertise that greatly assisted the research and we thank to "anonymous" reviewers for their so-called insights.

\section{References}

Andersen, L.E., \& Tejerina, O.J.M. (2007). "A Micro-Level Dynamic Analysis of The Effects of Remittances on Social Mobility, Schooling, Work, Consumption and Investment in Nicaragua". Grupo Integral, Study No. GIE12

Arulampalam, W (1998). "A Note on Estimated Coefficients in Random Effects Probit Models". Department of Economics, University of Warwick, Coventry, CV4 7AL, U.K. 
Bandara, A., Dehejia, R., \& Rouse, S.L. (2014). "The Impact of Income and Non-Income Shocks on Child Labor: Evidence from a Panel Survey of Tanzania". World Development Vol. 67, pp. 218-237, 2015. 0305-750X/_ 2014 Elsevier Ltd. All rights reserved

Barros, R., Mendonça, R \& Velazco, T. (1994). "Is Poverty The Main Cause of Child Work in Urban Brazil?" Rio de Janeiro, Texto para Discussão No. 351, Instituto de Pesquisa Econômica Aplicada

Beegle, K., Dehejia, R.H \& Gatti, R. (2006). "Child Labor and Agricultural Shocks". Journal of Development Economics 81:80-96

Bhalotra, S. \& Heady, C. (2003). "Child Farm Labor: The Wealth Paradox". The World Bank Economic Review, 17, 197-227

Cameron, L (2001). "The Impact Of The Indonesian Financial Crisis On Children: An Analysis Using the 100 Villages Data" Bulletin of Indonesian Economic Studies, Vol. 37, No. 1, 2001: 43-64

Cameron, L \& Worswick, C (2001). "Education Expenditure Responses to Crop Loss in Indonesia: A Gender Bias. University of Chicago.

Cameron, L \& Worswick, C (2003). "The Labor Market as a Smoothing Device: Labor Supply Responses to Crop Loss." Review of Development Economics 7, no. 2: 327-341.

Debebe, Y, Z. (2010)" Sharing in Rural Ethiopia". Working Paper No. 491. International Institute of Social Studies of Erasmus University Rotterdam (ISS), The Hague.

Dehejia, R \& Gatti, R (2002). "Child Labor: The Role of Income Variability and Access to Credit Across Countries". NBER Working Paper No. 9018

Dercon, S (2005). "Insurance against Poverty (UNU-WIDER Studies in Development Economics). Oxford University Press
Dillon, A (2008). "Child Labor and Agricultural Production in Northern Mali". A Dissertation. Faculty of the Graduate School of Cornell University

Dreze, J., \& Sen, A. (2011). "Hunger and Public Action. WIDER Studies in Development Economics". Oxford: Oxford University Press.

Duryea, S., \& Kuenning, M.A. (2001). "School Participation, Child Labor and Local Labor Market Fluctuations in Urban Brazil." Prepared for presentation at the conference "Crises and Disasters: Measurement and Mitigation of their Human Costs" organized by the IDB and IFPRI

Fitzsimons, E., (2007.) "The Effects of Risk on Education in Indonesia”. Institute for Fiscal Studies. Journal of Economic Development and Cultural Change. Volume, issue, pages: Vol. 56, No. 1, pp. 1-25

Greene, W., \& McKenzie, C. (2012) "An LM Test Based On Generalized Residuals for Random Effects in A Nonlinear Model". Economics Letters. Volume 127, February 2015, Pages $47-50$

IFAD (2011)."Mendorong Masyarakat Miskin di Perdesaan untuk Mengatasi Kemiskinan di Indonesia”. Viewed February 20, 2013.

Jacoby, H., \& Skoufias, E., (1997). "Risk, Financial Markets, and Human Capital in a Developing Country". Review of Economic Studies LXIV, 311 - 335

Kochar, A (1999a), "Smoothing Consumption by Smoothing Income: Hours-of-Work Responses to Idiosyncratic Agricultural Shocks in Rural India," Review of Economics and Statistics 81 (1), 50-61.

Kruger, D. I. (2004). "Coffee Production Effects on Child Labor and Schooling in Rural Brazil. "Journal of Development Economics 82(2):448-63. 
Avalaible online at http://journals.ums.ac.id

Jurnal Ekonomi Pembangunan, 18 (1), 2017, 19-39

Levinsohn, J.A., Berry, S.T., \& Friedman, J. (2003). "Impacts of the Indonesian Economic Crisis. Price Changes. National Bureau of Economic Research

Nguyen, T., \& Purnamasari, R. (2011).”Impacts of International Migration and Remittances on Child Outcomes and Labor Supply in Indonesia : How Does Gender Matter? Policy Working Paper 5591. The World Bank East Asia and Pacific Region Poverty Reduction and Economic Management Unit

Priyambada, A., Sumarto, S., \& Suryahadi, A. (2005). "What Happened to Child Labor in Indonesia during the Economic Crisis? The Trade-off between School and Work". SMERU Working Paper

Skoufias, E., \& Parker, S.W. (2002). "Labor market shocks and their impacts on work and schooling: Evidence from urban Mexico. Food Consumption and Nutrition Division". Discussion Paper 129. Washington, D.C.: International Food Policy Research Institute

Thomas, D., \& Frankenberg, E. (2004). "Household Responses to the Financial Crisis in Indonesia: Longitudinal Evidence on Poverty, Resources, and Well-Being". University of Chicago Press

Townsend, R., (1994). "Risk and Insurance In Village India”. Econometrica LXII, 539- 591.

UNDP (2007). "Sisi Lain Perubahan Iklim : Mengapa Indonesia Harus Beradaptasi Untuk Melindungi Rakyat Miskinnya”. United Nations Development Programme Indonesia 
Avalaible online at http://journals.ums.ac.id

Jurnal Ekonomi Pembangunan, 18 (1), 2017, 19-39

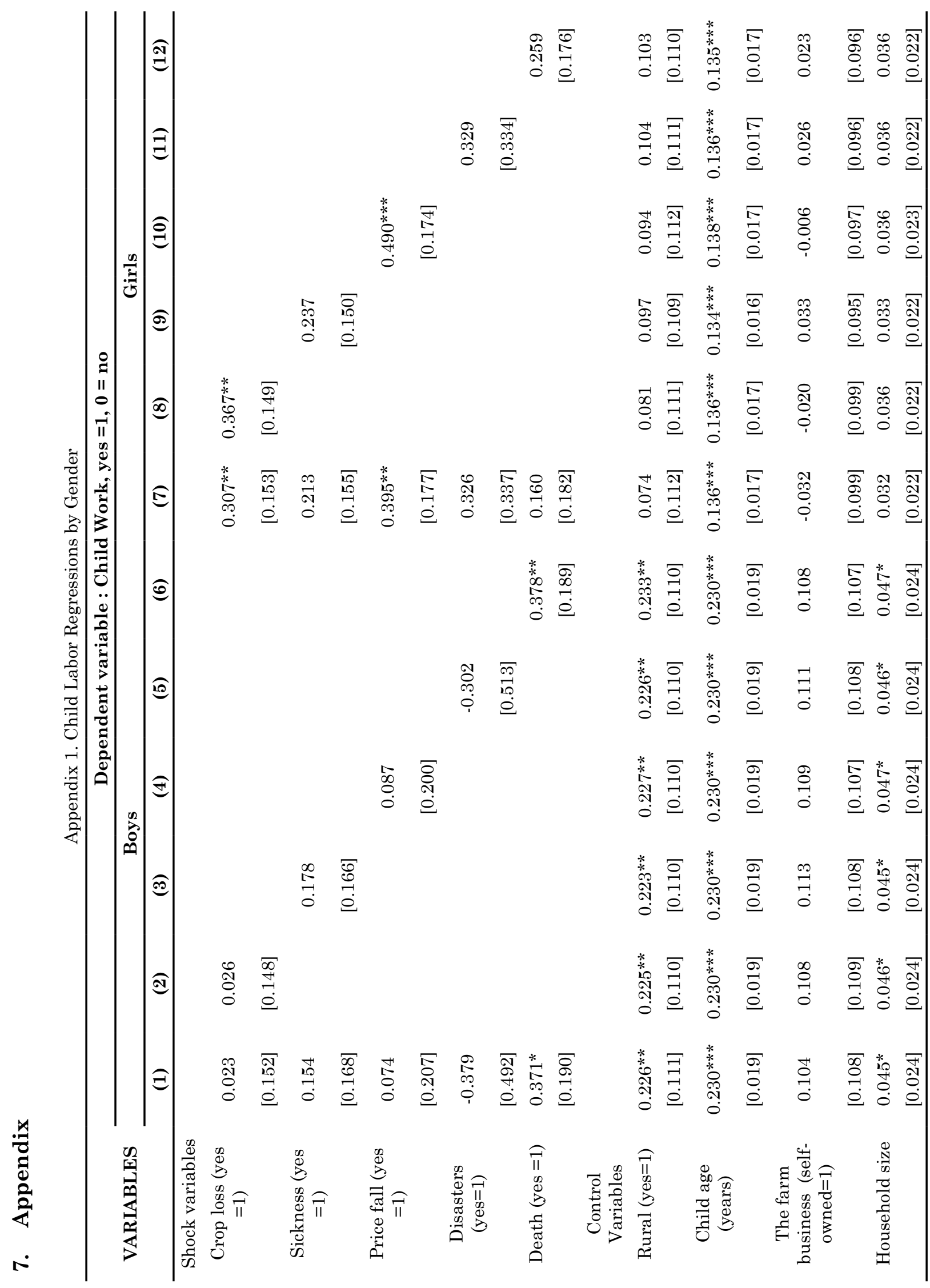

Jurnal Ekonomi Pembangunan, ISSN 1411-6081, E-ISSN 2460-9331 
Avalaible online at http://journals.ums.ac.id

Jurnal Ekonomi Pembangunan, 18 (1), 2017, 19-39

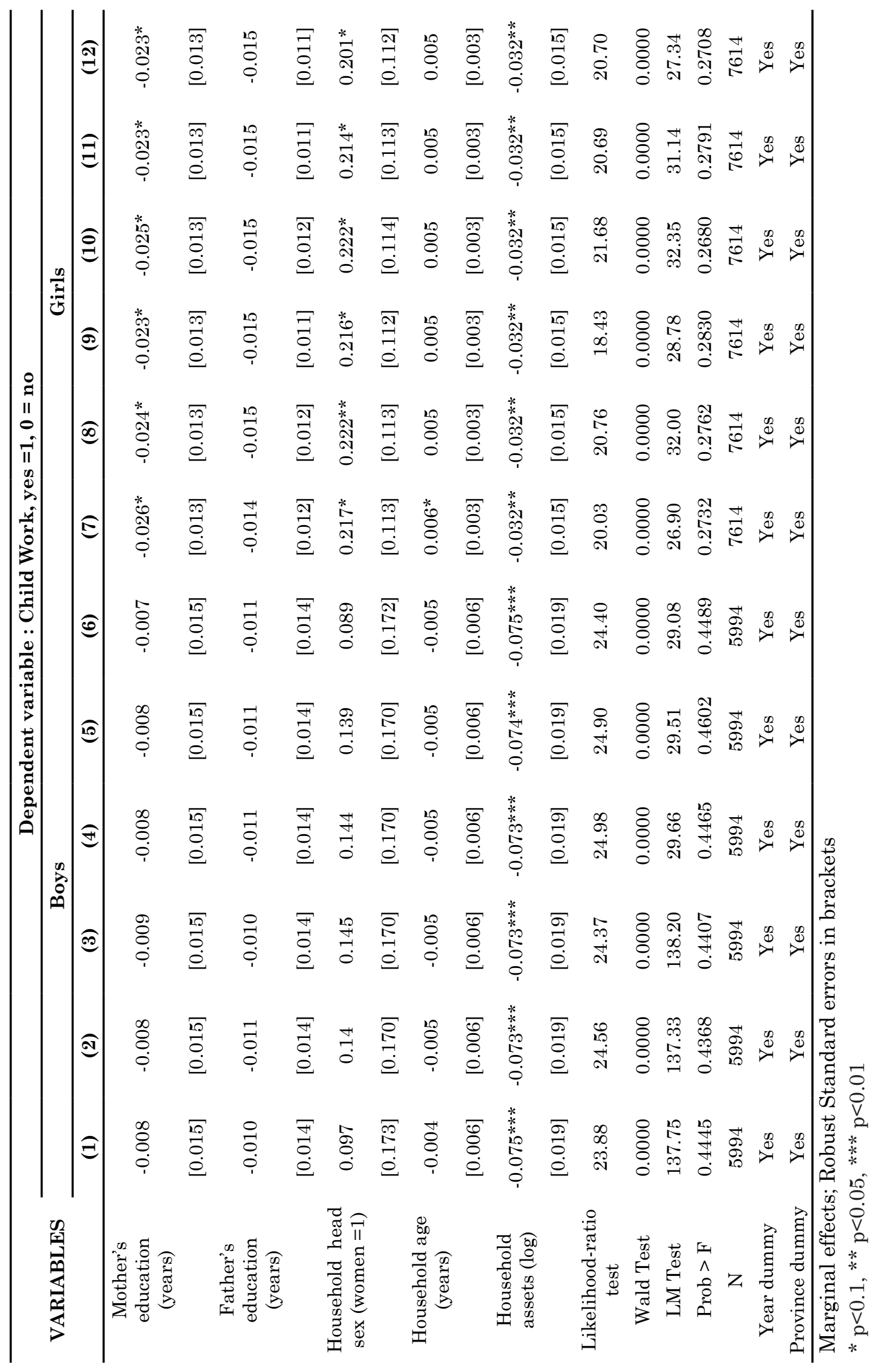


Avalaible online at http://journals.ums.ac.id

Jurnal Ekonomi Pembangunan, 18 (1), 2017, 19-39

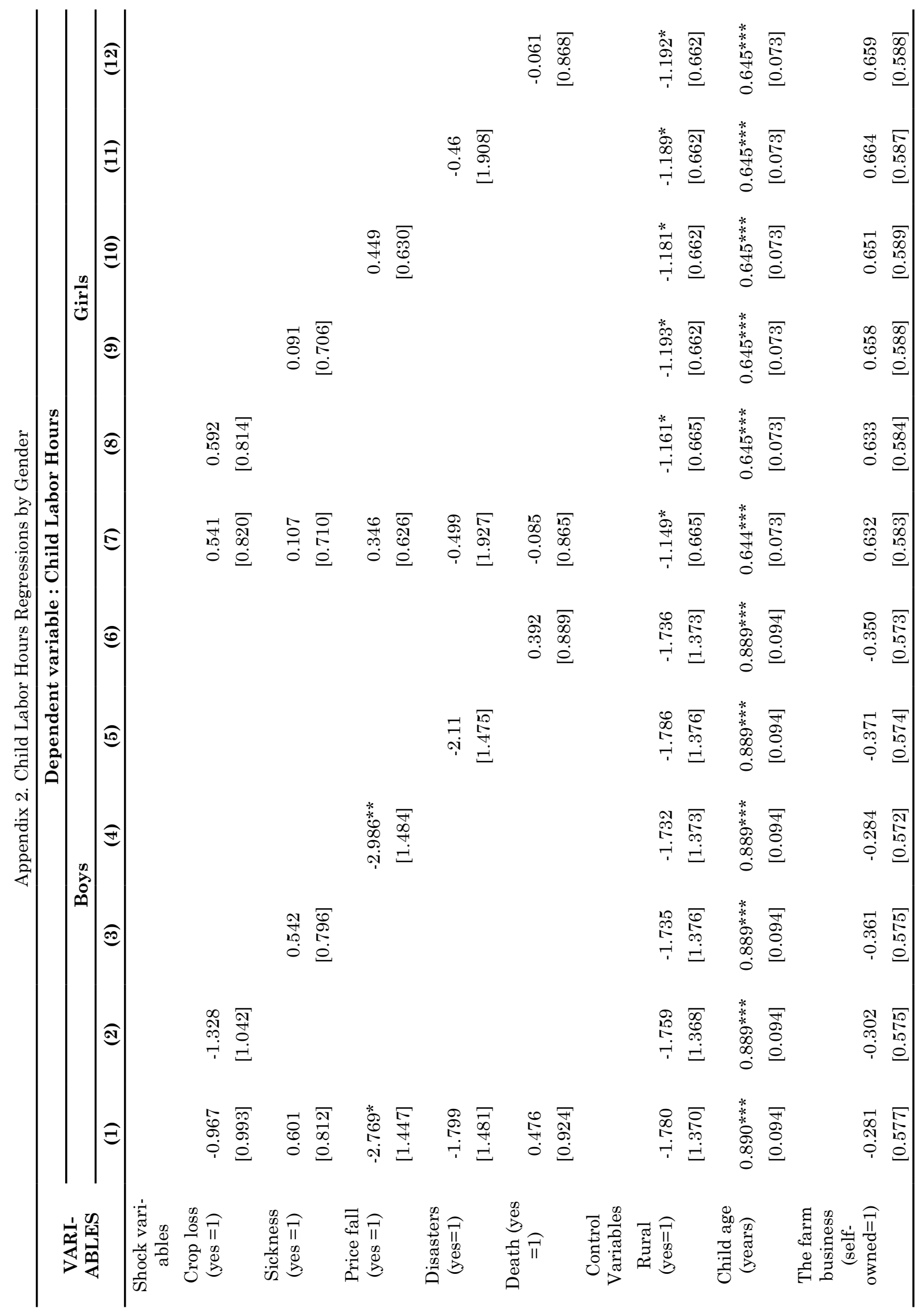

Jurnal Ekonomi Pembangunan, ISSN 1411-6081, E-ISSN 2460-9331 
Avalaible online at http://journals.ums.ac.id

Jurnal Ekonomi Pembangunan, 18 (1), 2017, 19-39

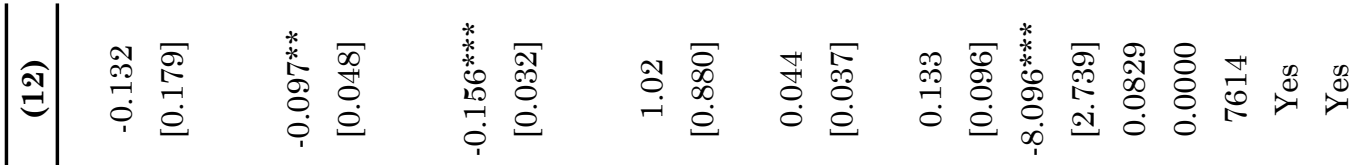

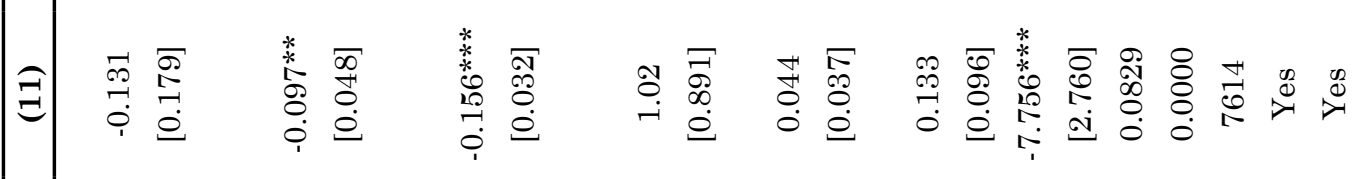

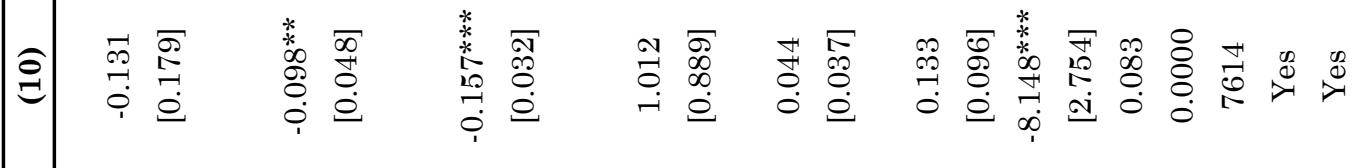

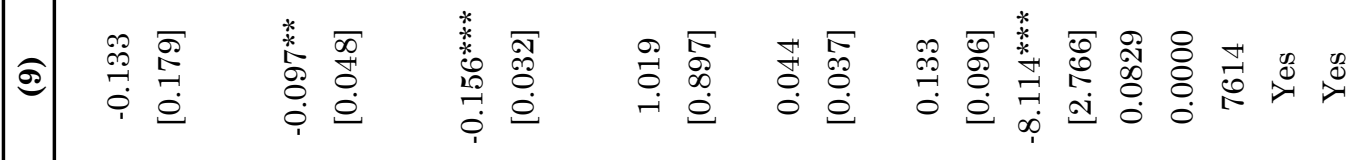

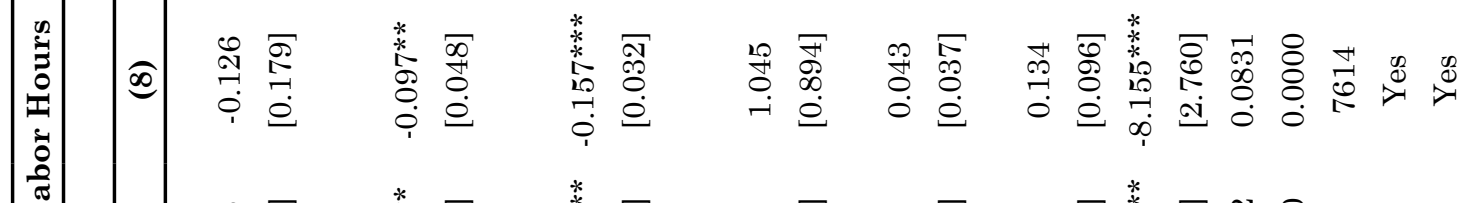

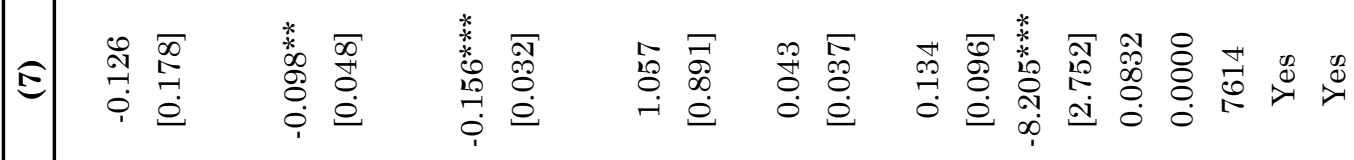

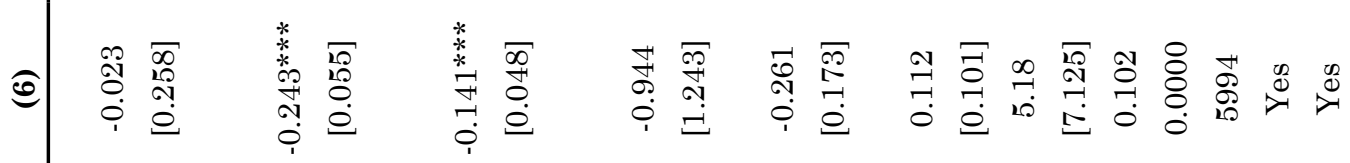

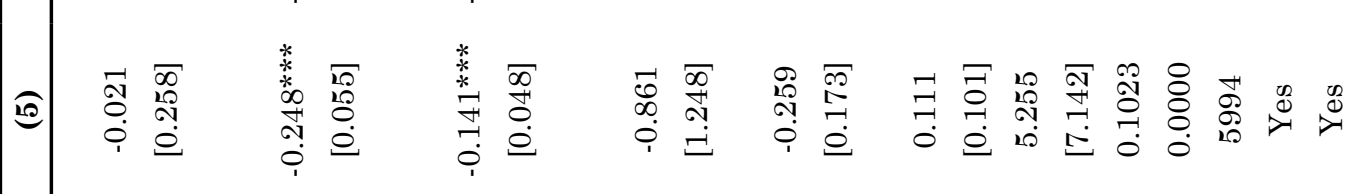

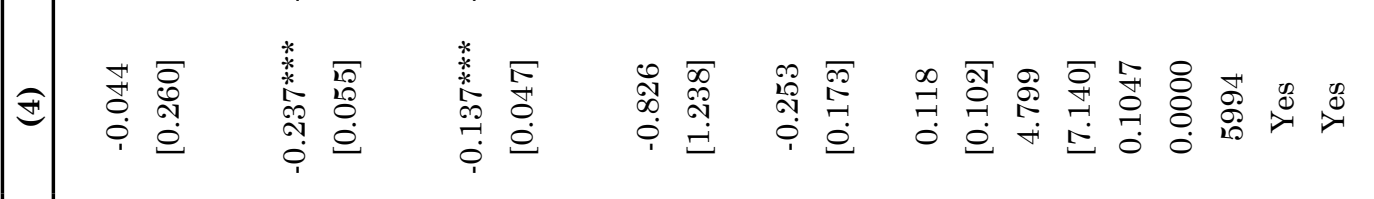

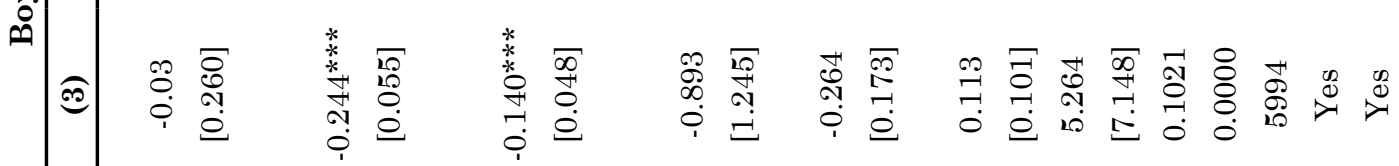

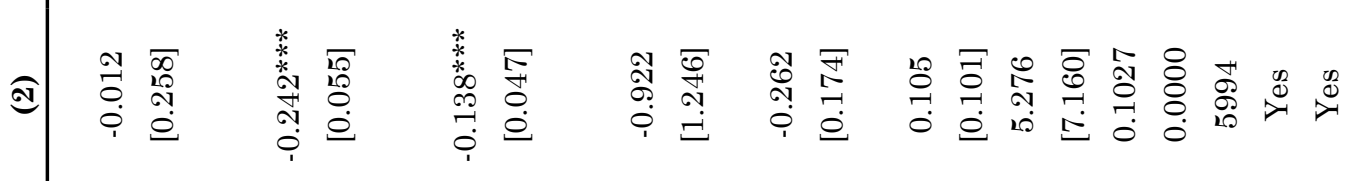

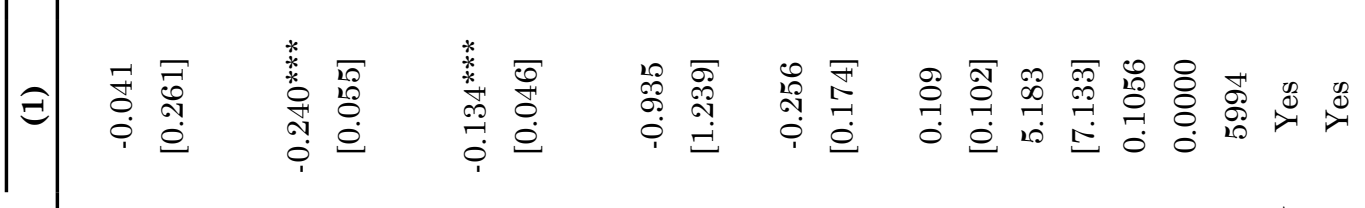

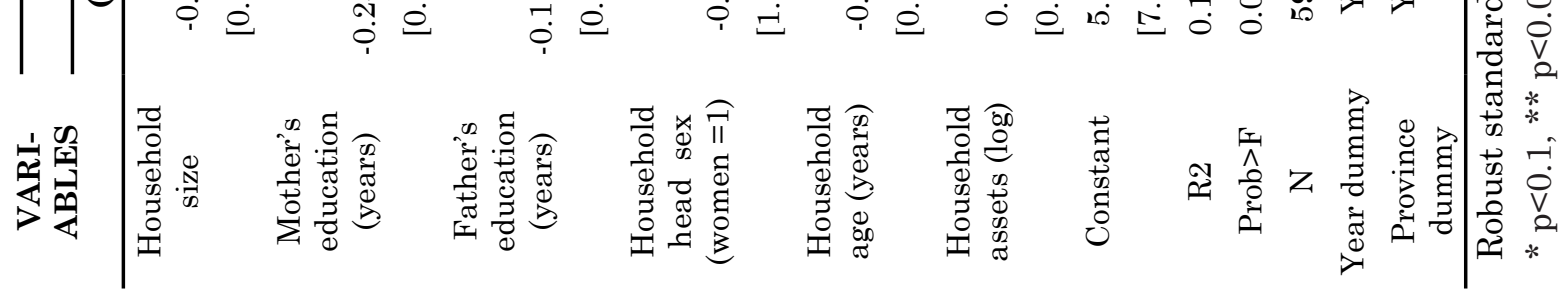


Avalaible online at http://journals.ums.ac.id

Jurnal Ekonomi Pembangunan, 18 (1), 2017, 19-39

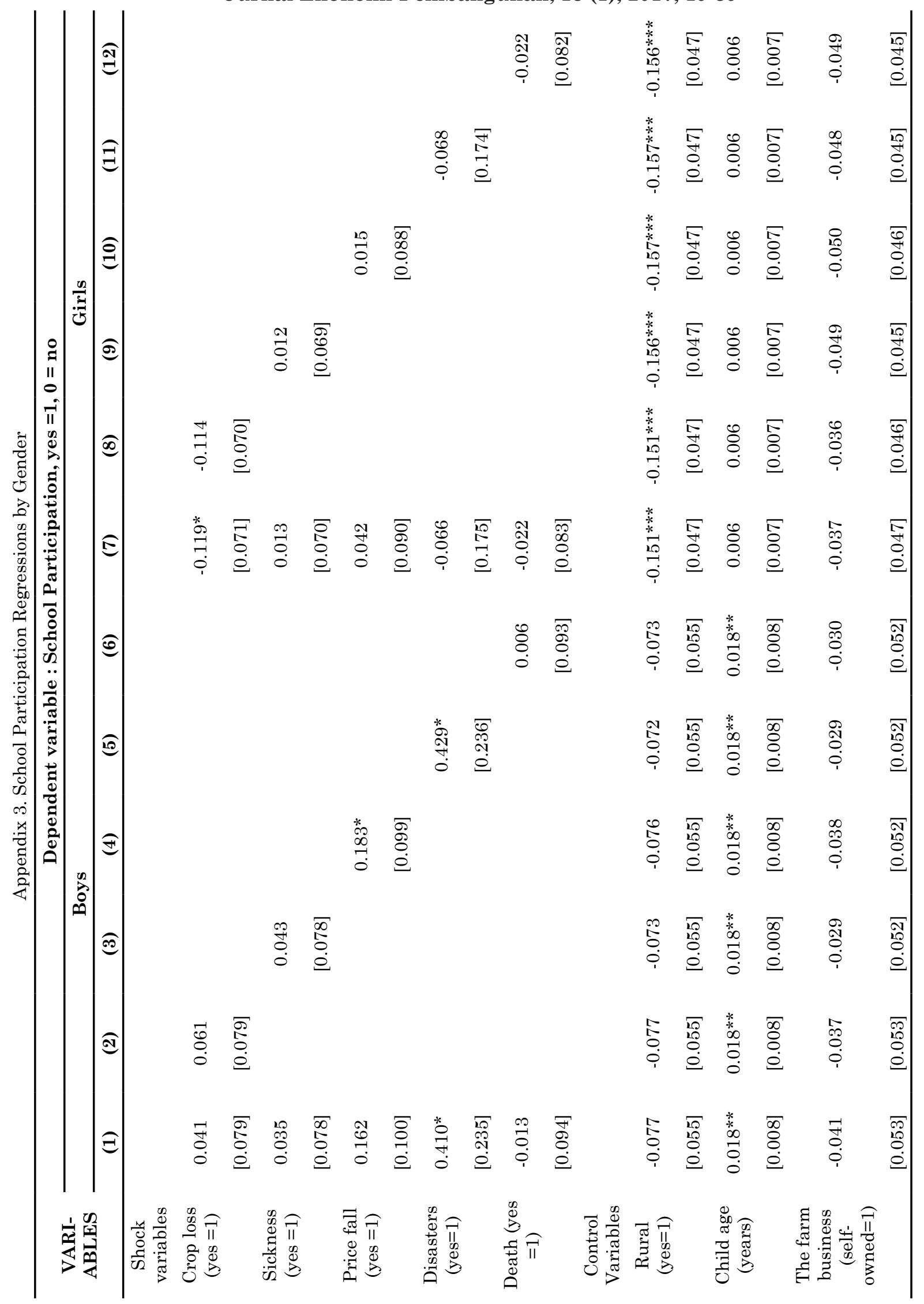


Avalaible online at http://journals.ums.ac.id

\section{Jurnal Ekonomi Pembangunan, 18 (1), 2017, 19-39}

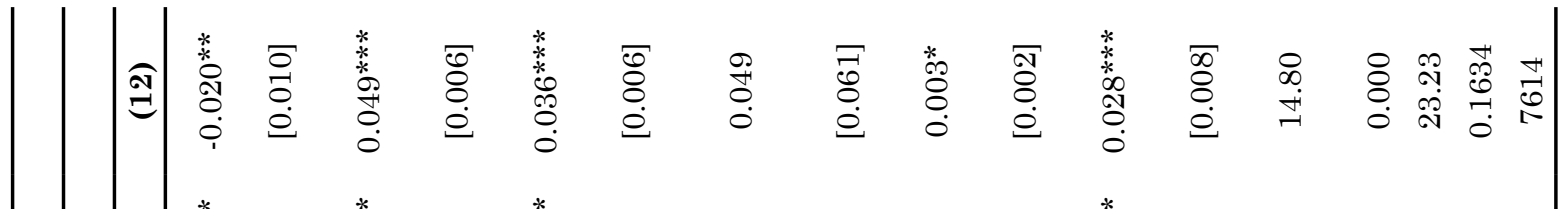

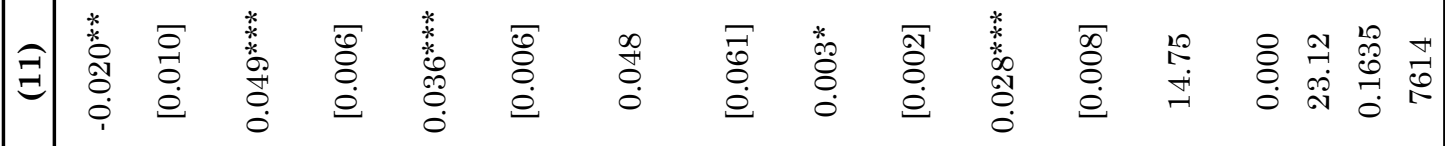

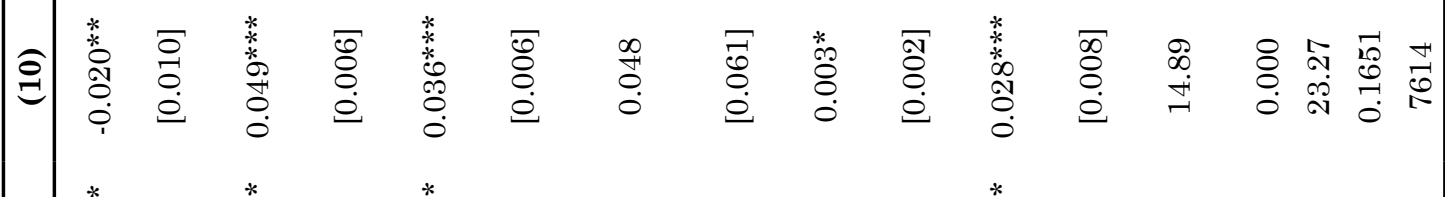

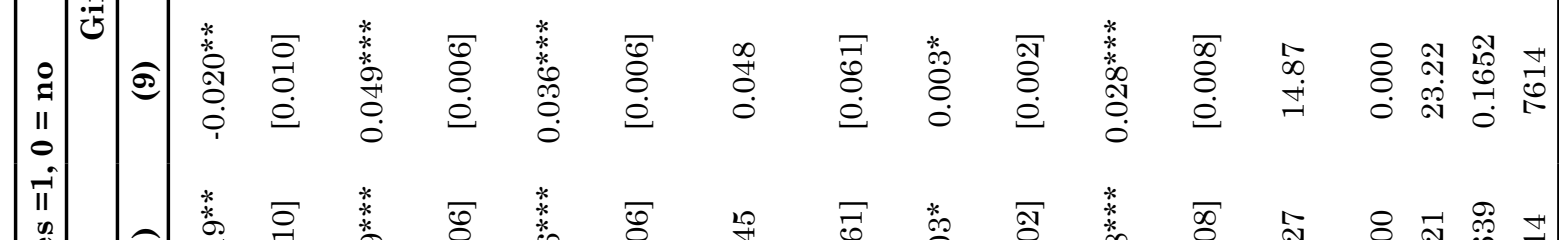

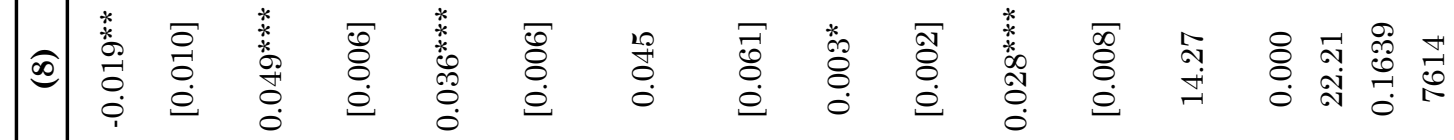

$$
\begin{aligned}
& \text { E }
\end{aligned}
$$

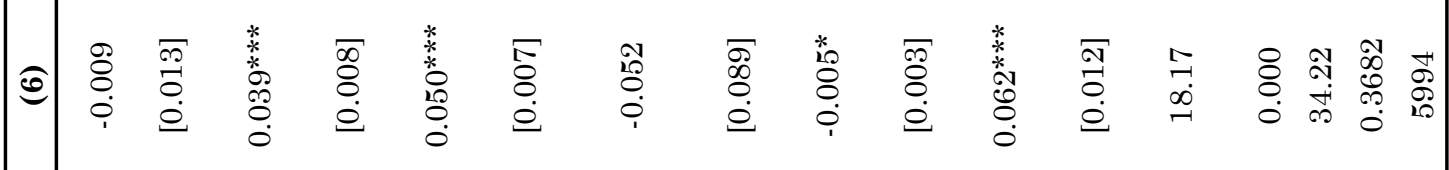

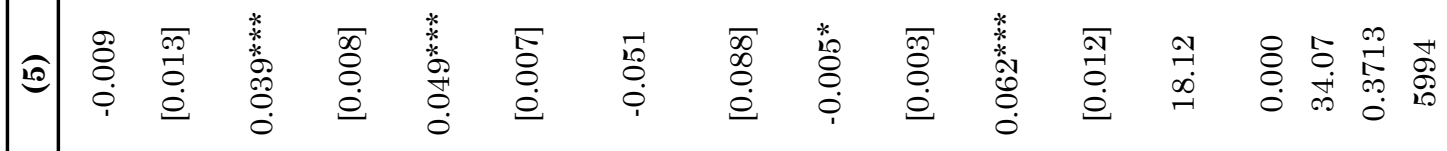

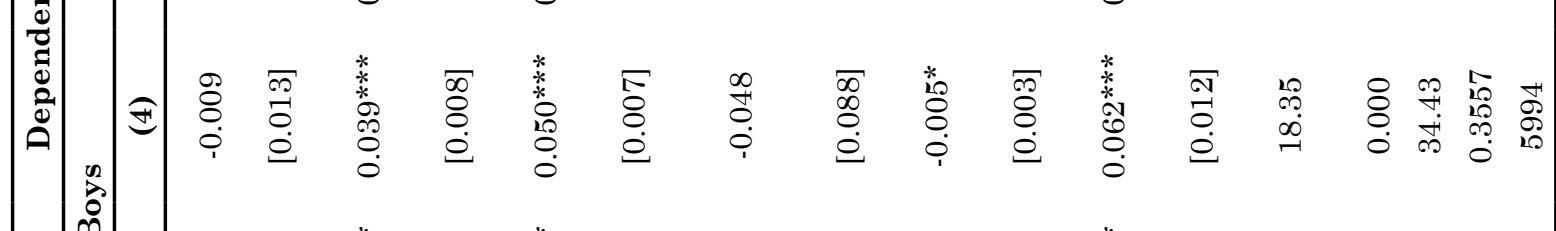

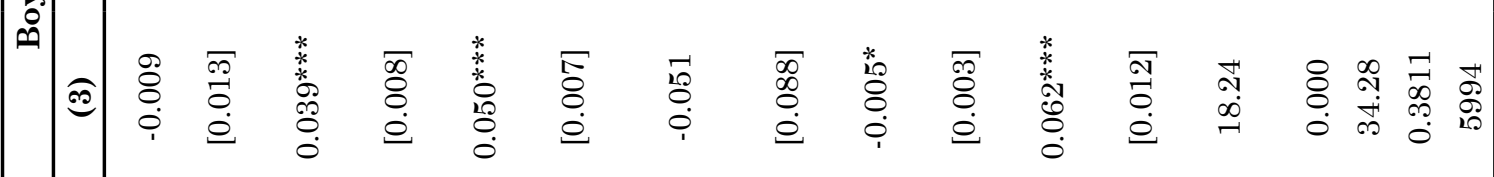

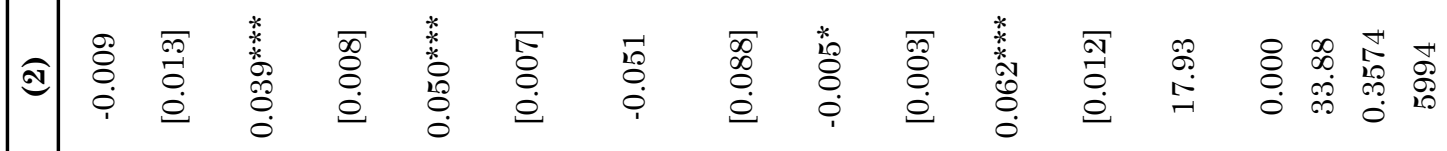

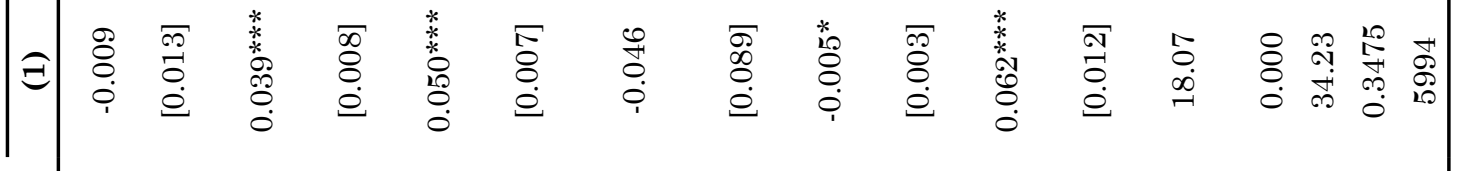

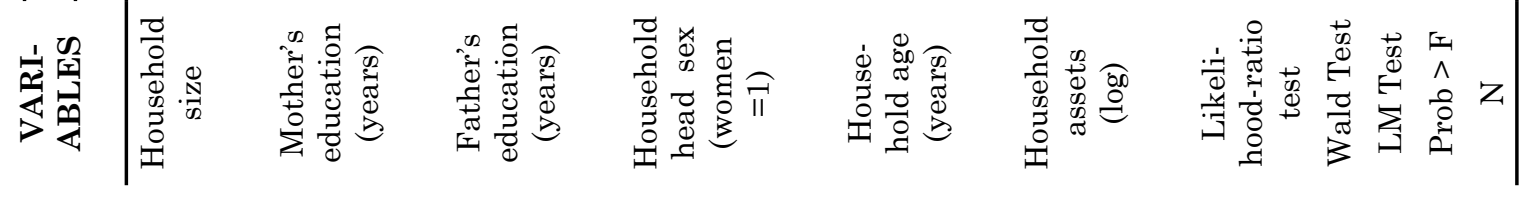


Avalaible online at http://journals.ums.ac.id

Jurnal Ekonomi Pembangunan, 18 (1), 2017, 19-39

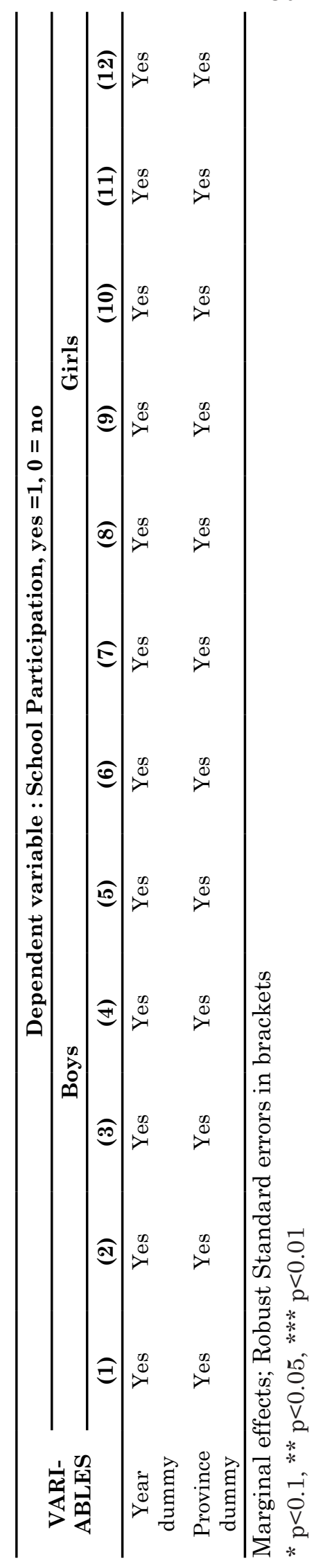

